\title{
The Politics and Place of a "Legendary" Hip Hop Track in Detroit
}

\author{
REBEKAH FARRUGIA AND KELLIE D. HAY
}

See the headlines; We are disenfranchised, but when we got lemons, what we do? Make that lemon pie! And that's why, I walk with my head high, cuz it's twice as hard as a chick but I get by and stay fly.

— 'Nique LoveRhodes, "Legendary.”

\section{Introduction}

Women in Detroit engaged in the city's history and struggle are making statements like the one above every day in numerous artistic and activist contexts. The particular stanza quoted above is part of a larger verse of the rap song and music video "Legendary." Created in a somewhat unusual context, "Legendary" is the product of the Foundation, a socially conscious local women's hip hop collective that consists of artists, activists, and academics. Members of the Foundation worked collectively to produce the track and video with the aim of foregrounding a women-centered depiction of Detroit and gesturing towards solutions for overcoming the contemporary environmental and social conditions consuming the city and its citizens. "Legendary" captures the ways in which strong women imagine racial injustice, environmental ruin, and social abandonment. These issues are not unusual in Detroit; rather, they are all too familiar. ${ }^{1}$ However, the process of collaboration that went into the production of "Legendary" is atypical.

The subjects addressed in this paper came to fruition after the authors received and answered an unconventional call for submissions for the second annual Ecomusicology Listening Room (ELR2) scheduled for the American Musicological Society (AMS) conference held in Pittsburgh, Pennsylvania, in fall 2013 (http://ecosong.org/elr2-2013.html). The call invited participants to consider the intersections of

\footnotetext{
We are grateful to our editor, Tyler Kinnear, for his insiteful, substantive suggestions. We also thank the reviewers of this issue of Music \& Politics for their thoughtful comments as well as Mark Pedelty and Justin Burton for selecting us to participate in the Ecomusicology Listening Room 2 session at the 2013 American Musicological Society conference. We are indebted to the Foundation collective for their time and their diligence, love, and commitment to hip hop culture. A portion of this essay was presented at the International Association for the Study of Popular Music-U.S. conference in Chapel Hill, North Carolina, March 16, 2014.

${ }^{1}$ Dominic Capeci Jr. and Martha Wilkerson, in Layered Violence: The Detroit Riots of 1943 (Jackson, MS: University of Mississippi Press, 1991), critique the established mythology as to what caused the riots in Detroit during World War II; Reynolds Farley, Sheldon Danziger, and Harry Holzer, in Detroit Divided (New York: Russell Sage Foundation, 2000), investigate the roots of contemporary inequality in Detroit, focusing on labor force issues and economic equality; David Harvey, in Social Justice and the City, 2nd ed. (Baltimore: Johns Hopkins, 2009), reconceptualizes urban development, looking at larger issues of economic development and the use of space. See also Heather Ann Thomson, Whose Detroit?: Politics, Labor, and Race in a Modern American City (Ithaca: Cornell University Press, 2000). Thompson examines the causes of the 1967 rebellion as well as the attempts to reconstruct frameworks of power in the city's economy. The primary focus is the UAW but there are implications for larger reimaginings of the city.
} 
music, image, and place in a format that combined music, video, and scholarship. In our view, this call and session opened a space that is not only interventionist in a disciplinary sense, but also has the potential to reach audiences far outside of academia.

For the past two years we have been working on an ethnographic project that focuses on women in the Detroit hip hop scene. The majority of our fieldwork has focused on the work of the Foundation. As researchers, we entered the collective as white, middle class women, albeit ones who were raised in working class families. We are both hip hop fans, and while we spend a great deal of time in the city, we are not Detroiters; we live north of the dividing line of 8 Mile Road. Moreover, we are not as immersed in local black culture as our participants. These differences require us to constantly reflect on our social locations. In her article, "The Problem of Speaking for Others," Linda Alcoff provides classic lessons that compel us to scrutinize our practices of participation and representation. ${ }^{2}$ We aim not "to speak for others" like the women in the Foundation but to work with and produce discourse in dialogue with the collective. Staying close to the creative, musical lives of the Foundation artists is not only a necessary part of music ethnography, but it also creates opportunities for our collective professional development. Thus, upon reading the AMS call, we approached the Foundation about the possibility of creating a track and video that spoke to the collective's thoughts on the relationship between music, politics, and space. The Foundation was eager to participate and so the planning began. Emerging from a collective social imaginary rooted in Detroit, we answered the call with the beats and lyrics of women-identified hip hop that focused on the imagery of failed urban renewal and local efforts to reclaim ecological and economic sustainability.

Video Example 1: Foundation Music Video

View at: http://dx.doi.org/10.3998/mp.9460447.0008.203

For many, the words "environment" and "ecology" conjure ideas and images of nature, both mediated and unmediated by humans. Several of the participants in the Ecomusicology Listening Room brought together audio and video tracks to make statements about various relationships between humanity, technology, and nature. In thinking about the connection between Detroit and rap music, our attention turned to the city's industrial decline, environmental waste, and how citizens are responding to these issues. ${ }^{3}$ The manufacturing base that once powered Detroit has all but disappeared, pollutants like the city's incinerator remain highly controversial, and neighborhood associations and community-based organizations fight to keep these issues in the public eye. ${ }^{4}$ As industrial and economic decline persists,

\footnotetext{
${ }^{2}$ Linda Alcoff, “The Problem of Speaking for Others," Cultural Critique 20 (Winter 1991-92): 5-32. For a more contemporary reworking of this classic essay, see Tony E. Adams, "Speaking for Others: Finding the 'Whos' of Discourse," Soundings: An Interdisciplinary Journal 88, no. 3/4 (Fall/Winter 2005): 331-45.

${ }^{3}$ We are aware that rap music is one element of hip hop culture; yet for our purposes here we are using the terms rap and hip hop interchangeably. For more on the shifting meanings of hip hop and rap music see Adam Krims, Rap Music and the Poetics of Identity (Cambridge: Cambridge University Press, 2000).

${ }^{4}$ Detroit's incinerator has created a lot of controversy. The Press has captured the essences of the debate. However, town hall meetings are another form of discourse that showcase neighborhood associations' views. According to Joan Agosta, "The incinerator is one of the worst polluters in Wayne County (where Detroit is located) for criteria pollutants. It emits nitrogen oxides, sulfur dioxide, carbon monoxide and lead into the atmosphere-pollutants toxic to human health. In addition, the toxins emitted by the incinerator are particularly harmful to children's health. Particulate matter emissions contribute to Detroit's high asthma hospitalization and death." Joan Agosta, "Burning City Garbage in Detroit Short-Sighted and Very Harmful," Guelph Tribune, accessed May 12, 2014, http://www.guelphtribune.ca/opinion/burning-city-garbage-in-detroitshort-sighted-and-very-harmful.
} 
there is a growing interest in urban farming and habitat restoration. Consequently, an examination of the changes and threats that Detroit is facing is a valuable forum for critical discussion of the politics concerning the relationship between music and the environment. Given our interest in how hip hop culture can be used to build awareness and forge social and environmental change in struggling cities like Detroit, in this essay we draw on our experiences of creating the hip hop track "Legendary" as part of the Foundation. ${ }^{5}$ Our intention is to highlight some of the ways in which citizens of Detroit use rap music to create spaces of resistance to protect their environments, homes, jobs, and quality of life. We first contextualize the historical and contemporary environmental conditions of Detroit before moving on to describe the collective process of creating "Legendary." From there we theorize the relationship between music, place, and cultural production. In particular, we examine the ways in which "Legendary" engages issues of marginalization and reimagines the social, economic, and environmental conditions of life in a city most often defined by poverty and racial struggle.

This essay employs an interdisciplinary framework that draws on research from ecomusicology, popular music studies, urban geography, and urban planning. As Travis Stimeling notes, such intersections have only recently begun to receive attention in musicological studies. ${ }^{6}$ Commenting on the importance of musicological attention to environmental concerns, Aaron S. Allen explains, "musicologists can provide insight on how composers, musicians, and others react to and communicate about environmental problems in their works, performances, and communal music making; and we can consider how listeners and audiences react and respond to such experiences." Building on Allen's insights, we both draw on and situate this project within ecomusicology in an effort to understand and showcase the ways in which women in Detroit are using hip hop to communicate about their local environment and their place within it. Moreover, it also provides a ground for understanding how music is a strategic tool for both environmental awareness and change.

In the 1980s, musicologists began to call attention to the discipline's tendency to confine its area of study to the realm of aesthetics and meaning. Scholars such as Susan McClary and Lawrence Kramer launched a paradigmatic shift in the field as they drew on cultural and literary theory to articulate connections between music, politics, and identity. ${ }^{8}$ The Western art world's tendency to purposefully treat

\footnotetext{
${ }^{5}$ Contemporary cultural policy research, particularly policy that bears on heritage tourism, offers rich insights into the ways in which economics, culture, and identity are interwoven. In The Economics of Cultural Policy, David Throsby argues that cultural policy has become a much more complicated enterprise over time. About cultural policy in the 1990s Throsby writes, "The concern of cultural policy in those days was with the creative arts, how they contribute to a civilized society, how more people could be introduced to the benefits of artistic consumption, and how the arts content of education systems and the media could be improved." Today, he explains, "cultural policy has a widening reach." He defines cultural value and economic value before he focuses on the unique role that creative, cultural industries play in our economy. On Throsby's view, in addition to whatever commercial value cultural goods and services possess, they also "transcend any measurable monetary value." The extra value may include "spirituality, aesthetics, and cultural identity." David Throsby, The Economics of Cultural Policy (Cambridge: Cambridge University, Press, 2010), 16. Musical performance and music videos add cultural value to economic and ecological realities. Here cultural value offers more than economic benefit or exchange. It can be both motivational and mobilizing, a definite tool for social change. The struggle for sustainability can be deeply felt and heard through the vivid imagery, rhetorical invention, imaginative beats, and eloquent delivery coursing through "Legendary." ${ }^{6}$ Travis D. Stimeling, "Music, Place and Identity in the Central Appalachian Mountaintop Removal Debate," American Music 30, no. 1 (Spring 2012): 1-29.

${ }^{7}$ Aaron S. Allen, "Prospects and Problems for Ecomusicology in Confronting a Crisis of Culture," Journal of the American Musicological Society 64, no. 2 (Summer 2011): 417.

${ }^{8}$ Some of the most influential examples of this early work include Lawrence Kramer, Music as Cultural Practice: 1800-1900 (Berkeley, CA: University of California Press, 1993); Susan McClary, "Terminal Prestige: The Case of Avant-Garde Music Composition," Cultural Critique 12 (Spring 1989): 57-81; Susan McClary Feminine Endings: Music, Gender, and Sexuality (Minneapolis, MN: University of Minnesota Press, 1991).
} 
music as a museum piece disconnected from context or politics was being called out as a political move in itself. ${ }^{9}$ Building on this interdisciplinary cultural approach, ecomusicologists are bringing environmental factors to the fore. Thus far, ecomusicological studies have most commonly focused on the relationships between people and natural environments such as popular song's ability to reflect and affect contemporary attitudes toward rivers, the environmental impacts of massive mountaintop removal mining, and the ecological imprint of large scale events such as the excessive carbon footprint of U2's $360^{\circ}$ tour. ${ }^{10}$ To date, little attention has been paid to the musical compositions of marginalized groups including women and people of color.

Denise Von Glahn's Music and the Skillful Listeners: American Women Composers and the Natural World is a recent text that draws connections between music and the environment from the perspective of women. This study gives voice to nine middle class women who compose art music in an effort to explore the ways that they "have understood nature and expressed those understandings in their music." 11 Von Glahn offers some insightful conclusions pertaining to the composers' broad conceptions of nature and their overwhelming emphasis on collaboration "as a principal mode of behavior informing everything else." ${ }^{\prime 2}$ In justifying her limited focus on middle class white women who produce art music, Von Glahn mentions the compositions of African American composer Margaret Bonds (1913-1972). She goes on to point out that no systematic study has been undertaken that considers the experiences that African American women have with nature. Though we are not considering the work of African American composers of art music here, we are concerned with a similarly underrepresented group: African American women who produce hip hop. Our focus on the musical efforts of the Foundation draws attention to environmental sustainability issues specific to Detroit, extending this fruitful conversation from a focus on the aesthetics of art music to socially conscious rap music.

Despite a growing recognition that hip hop is an important form of environmental music and literature, it remains an understudied genre in musicology and so far has only received marginal attention from ecomusicologists. ${ }^{13}$ As far back as 1993, writing a year after the Los Angeles insurrection, Philip Bolhman observed, "rap music has yet to stir much of a response from the disciplines of musical scholarship"14 despite having "become one of the most convincing ways of encountering history." Two decades later Mark Pedelty concurs, "with its linguistic depth and topical range, hip-hop is particularly well equipped to deal with environmental matters." 16 Presently, socially conscious hip hop in particular embodies a sense of urgency and activism that is compatible with Aaron S. Allen's position that "ecomusicological approaches have the possibility to offer new social critiques about the intersections of

\footnotetext{
${ }^{9}$ Mark Pedelty, Ecomusicology: Rock, Folk, and the Environment (Philadelphia, PA: Temple University Press): 204.

${ }^{10}$ Nancy Guy, "Flowing Down Taiwan's Tamsui River: Towards an Ecomusicology of the Environmental Imagination," Ethnomusicology 53, no. 2 (Spring/Summer 2009): 220; see also Stimeling, "Music, Place and Identity," 6; Pedelty, Ecomusicology.

${ }^{11}$ Denise Von Glahn, Music and the Skillful Listeners: American Women Compose the Natural World(Bloomington, IN: Indiana University Press, 2013): 2.

${ }^{12}$ Ibid., 321.

${ }^{13}$ The following texts make a strong case for these lines of inquiry: David Ingram, The Jukebox in the Garden: Ecocriticism and American Popular Music Since 1960 (Amsterdam: Rodopi, 2010); Debra J. Rosenthal, “'Hoods and the Woods: Rap

Music as Environmental Literature,” The Journal of Popular Culture 39, no. 4 (Summer 2006): 661-76; and Pedelty, Ecomusicology.

${ }^{14}$ Philip Bolhman, "Musicology as a Political Act," The Journal of Musicology 11, no. 4 (Autumn 1993): 414.

${ }^{15}$ Ibid., 434.

${ }^{16}$ Pedelty, Ecomusicology, 67.
} 
music, culture, and nature-and, in general, about the world around us." ${ }^{17}$ Similarly, Alexander Rehding states that what binds ecomusicology is a sense of urgency, praxis, and activism. ${ }^{18}$ Detroiters are feeling an acute sense of urgency, if not emergency, about the material, economic, political, and social conditions in which they are living. These battles are perhaps most apparent in the emergency financial management struggle as well as Detroit's Future City vision for urban renewal, two issues we discuss in detail below.

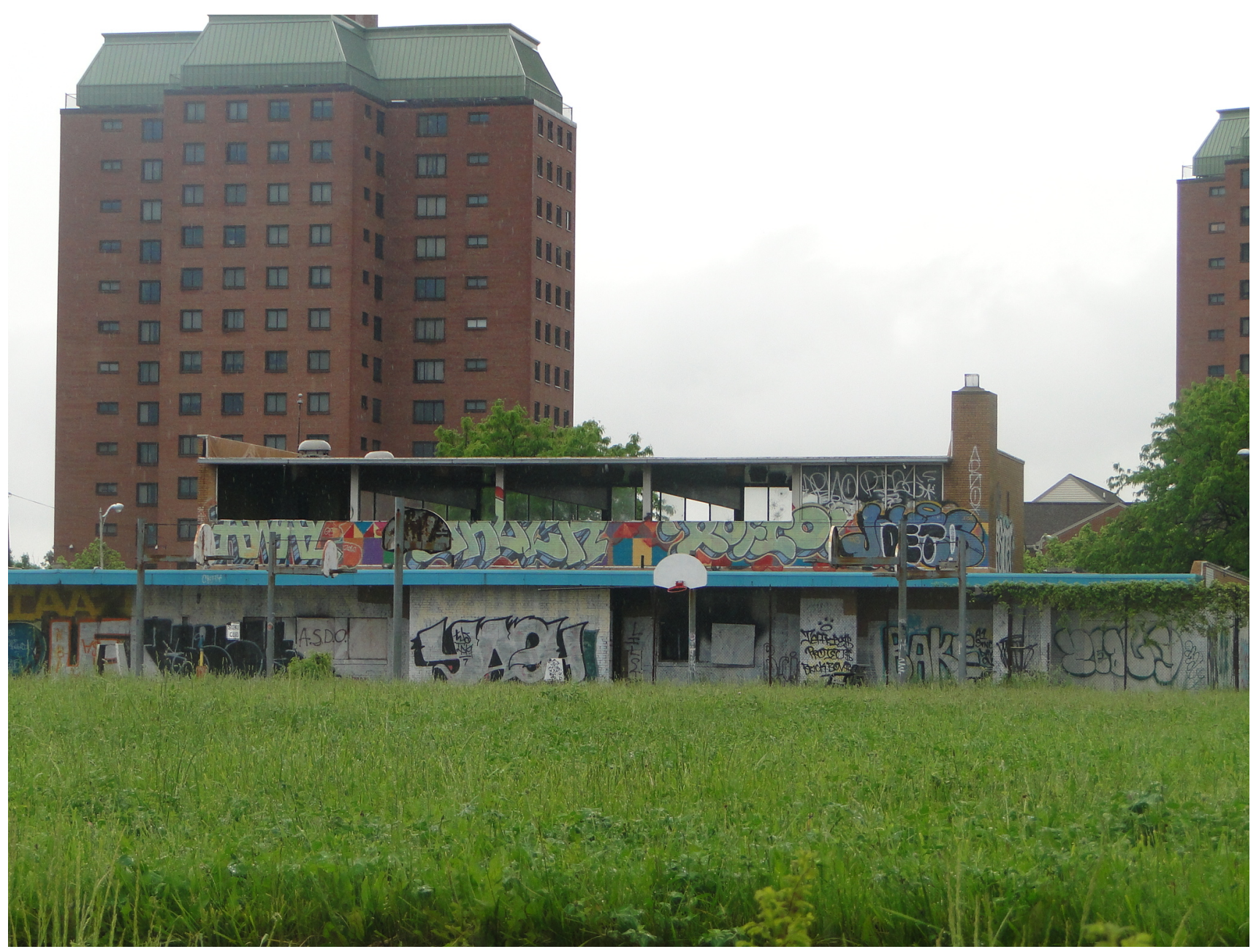

Image 1: Closed, crumbling school on the South side of the Cass Corridor

\footnotetext{
${ }^{17}$ Allen, "Prospects and Problems," 419.

${ }^{18}$ Alexander Rehding, "Ecomusicology between Apocalypse and Nostalgia," Journal of the American Musicological Society 64, no. 2 (Summer 2011): 409-14.
} 


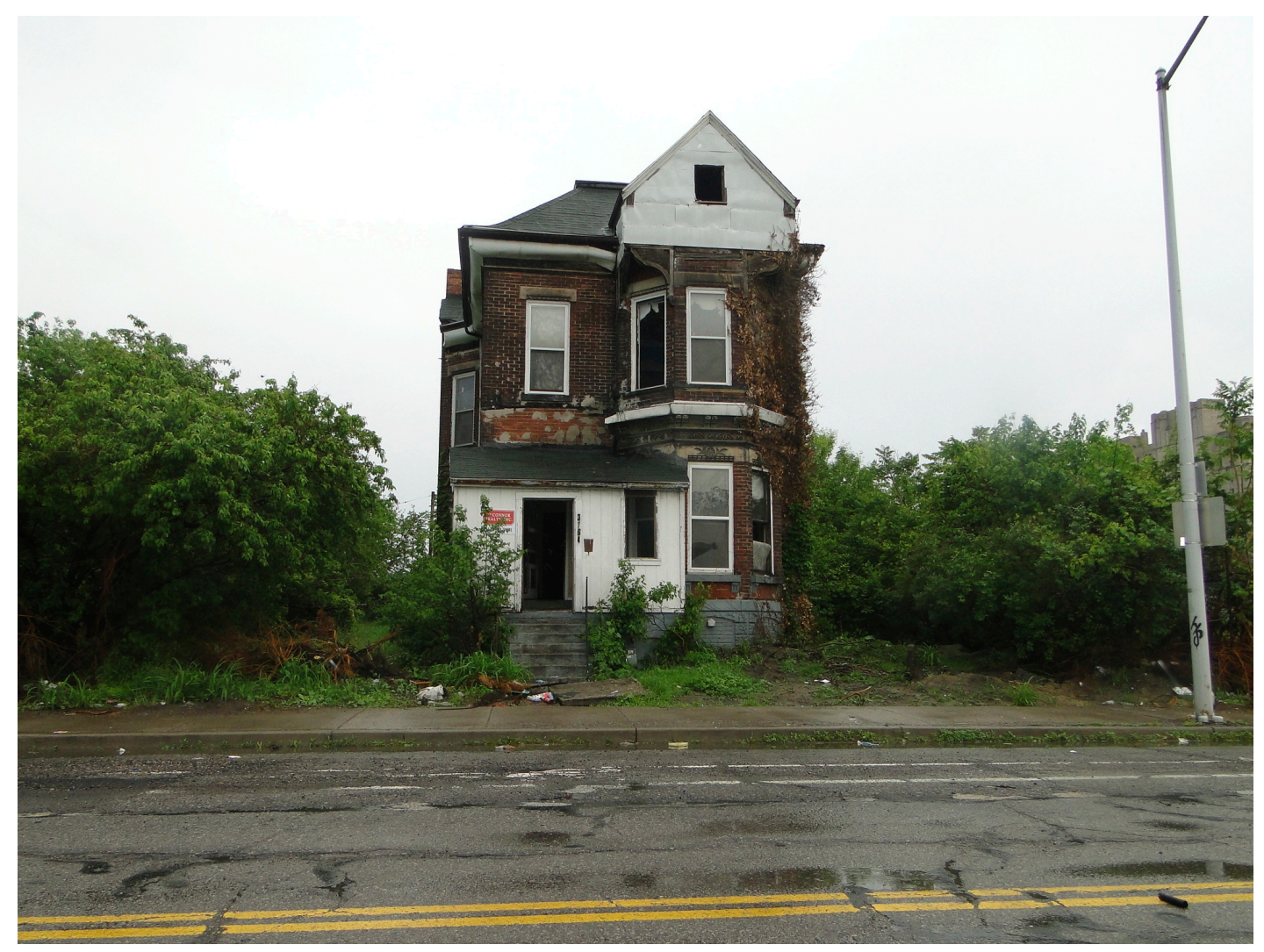

Image 2: Abandoned house in the center of the Cass Corridor

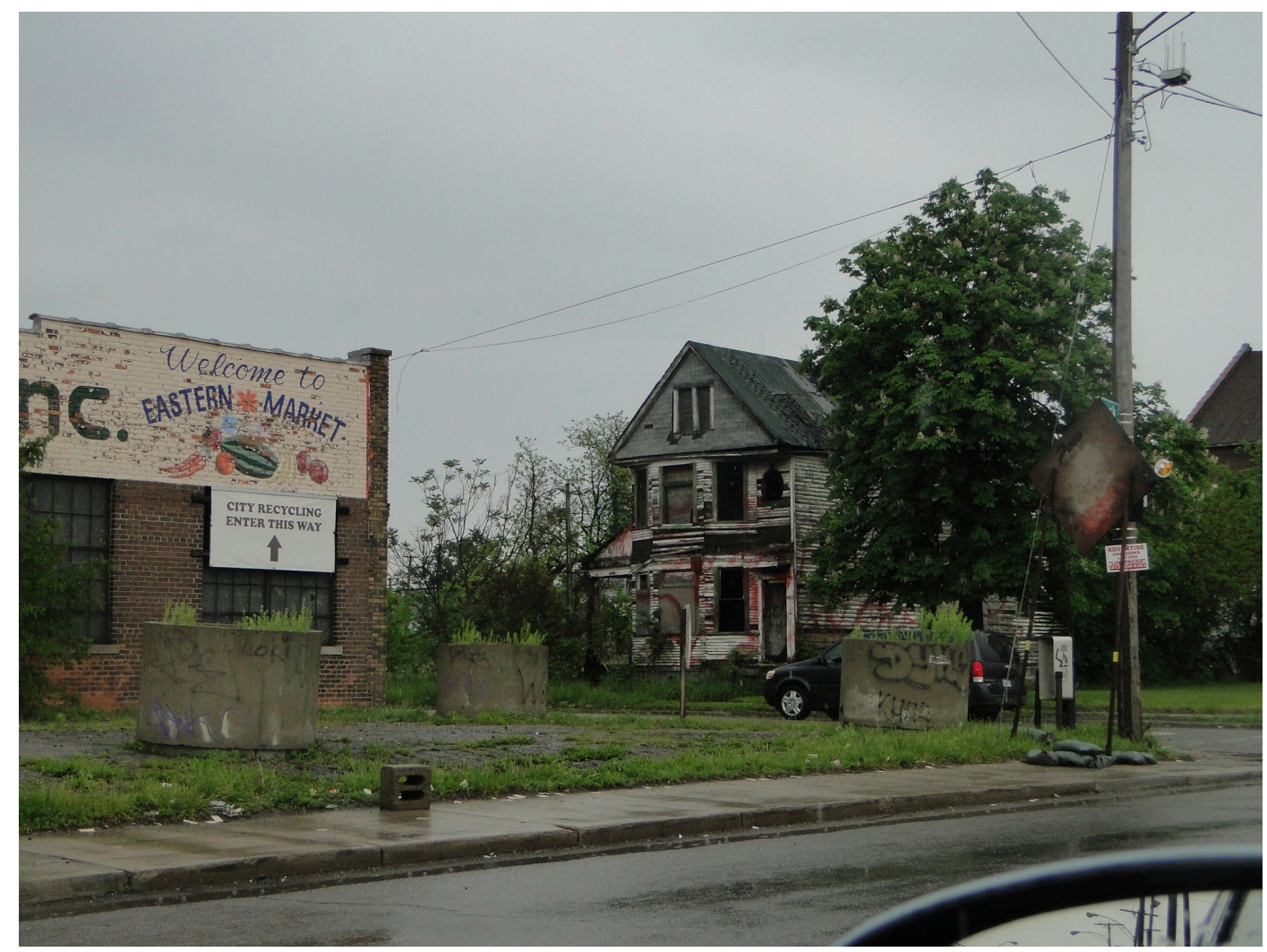

Image 3: Abandoned house, repurposed by the homeless, at the edge of the Eastern Market on Detroit's Eastside 


\section{Music, Place, and Detroit's Ethos}

In the 1970s, observing that the soundscape of the world was changing, R. Murray Schafer called for researchers from several independent areas of sonic studies to begin conversing with one another in an effort to further our understanding of the relationship between people and the sounds of their environments. ${ }^{19}$ Concurrently, in Noise: The Political Economy of Music, Jacques Attali called for the imagination of "radically new theoretical forms, in order to speak to new realities" and claimed that music was one such form. To this end, he urged scholars "not only to theorize about music, but to theorize through music." ${ }^{20}$ Since these crystallizing moments of soundscape studies, sound has received greater recognition as a methodology for social research. ${ }^{21}$ In the 1990s Susan J. Smith took up the ongoing social research bias towards the visual and urged scholars, particularly geographers, to pay more attention to the significance of sound in their interpretations of the cultural landscape. ${ }^{22}$ Building on Schafer and Attali, Smith argued that "sound, especially in the form of music, has a social and political significance which, if it could be heard, might influence, change or enrich the interpretation of particular scenes." 23 Quoting John Shepherd she adds, "music can illuminate the nature of our relationships to each other and to the environment." ${ }^{24}$ In the twenty years that have elapsed since Smith's call to action, scholars across disciplines have delved deeper into the study of music's relationship to politics and place. As Jonathan Sterne notes, increasing attention is being paid to how acoustic space functions in public space. ${ }^{25} \mathrm{~A}$ recent example of this attentiveness is Marina Peterson's ethnographic study Sound, Space, and the City: Civic Performance in Downtown Los Angeles, which explores "the meanings and makings of the civic" through the conception and production of free summer concert series. In Peterson's words,

civic performance offers a locus for understanding intersections of broader concerns facing urban residents and scholars, including social relations and diversity, public space and civic life, privatization and suburbanization, and economic and cultural globalization. ${ }^{26}$

She goes on to note that around the world similar projects are underway in an effort to "imagine" neighborhoods, activities, and developments. City-sponsored events designed to appeal to a diverse crowd provide the basis of her project. Examining these events, Peterson reveals the city's efforts to redefine spaces and increase civic engagement. Los Angeles's efforts to use music to engage the public speak to the goals and issues that conscious women rappers in Detroit not only face but openly engage.

While it is not a universal goal of hip hop artists to redefine spaces, it is common for MCs to call into question and/or reference places in their tracks for one purpose or another. Artists concerned with civic engagement and social justice issues purposefully do so to bring visibility to the poor conditions and

\footnotetext{
${ }^{19}$ R. Murray Schafer, The Tuning of the World (Philadelphia: University of Pennsylvania Press, 1980).

${ }^{20}$ Jacques Attali, Noise: The Political Economy of Music, trans. Brian Massumi (Manchester: Manchester University Press, 1985), 4, italics in original.

${ }^{21}$ See for example, Attali, Noise; Steven Feld, "From Ethnomusicology to Echo-Muse-Ecology: Reading R. Murray Schafer in the Papua New Guinea Rainforest," The Soundscape Newsletter 8 (June 1994): 9-13; Jonathan Sterne, ed., The Sound Studies Reader (New York: Routledge, 2012); Georgina Born, ed. Music, Sound and Space: Transformations of Public and Private Experience (Cambridge: Cambridge University Press, 2013).

${ }^{22}$ Susan L. Smith, "Soundscape," Area 26, no. 3 (Summer 1994): 232-40.

${ }^{23}$ Ibid., 234.

${ }^{24}$ Ibid.

${ }^{25}$ Jonathan Sterne, “Sonic Imaginations," in The Sound Studies Reader, ed. Johathan Sterne, 1-18 (New York: Routledge, 2012).

${ }^{26}$ Marina Peterson, Sound, Space, and the City: Civic Performances in Downtown Los Angeles (Philadelphia: University of Pennsylvania Press, 2012), 3.
} 
locations in which African Americans and other communities of color live. Others may heavily reference geographical place because it plays an important role in the development of diverse rap styles and differences in local hip hop cultures, even within the US. ${ }^{27}$ As Murray Forman notes in the introduction to The 'Hood Comes First: Race Space, and Place in Rap and Hip-Hop, "rap's lyrical constructions commonly display a pronounced emphasis on place and locality." ${ }^{28}$ In other words, rappers often explicitly reference particular streets, boulevards, neighborhoods and telephone area codes because of the tethering of socio-spatial information to locality, what Forman refers to as the extreme local. ${ }^{29}$ John Connell and Chris Gibson make a similar point:

Geographical space is not an 'empty stage' on which aesthetic, economic and cultural battles are contested. Rather, music and space are actively and dialectically related. Music shapes spaces and spaces shape music. In various ways sounds have been used to create spaces and suggest and stimulate patterns of human behavior in particular locations. ${ }^{30}$

Connell and Gibson's observation here is not specific to hip hop but it is useful in explaining why hip hop continues to be preoccupied with geographical space. Hip hop music originated on the streets of Brooklyn because of and in response to the poor material and economic conditions of its residents who were mainly people of color. Thus, from the beginning, hip hop culture recognized and was born out of this dialectic nature between geography and music.

The 5e Gallery, which currently hosts the Foundation, is one site of the extreme local to which Forman refers. Located in the Cass Corridor neighborhood on the lower level of a charming nineteenthcentury limestone building, it was once the exclusive property of Detroit Unitarian Church. Today, several community-based organizations rent space from the neighborhood association that owns the building. Given that so many activist organizations share space, people from spiritual, environmental, and youth communities circulate through the gallery. This flow of people leads to a great deal of collaboration, and hip hop is the vehicle that brings individuals from all of these different communities together. The Cass Corridor is very close to Wayne State University; as a result, students and professors know about the gallery and the Foundation. The promotional work of the Foundation has also led to connections with local business owners and the local press. Given its location, outreach, and principles, the Foundation purposefully employs hip hop to create a space for socially conscious women hip hop artists. The collective's creative work not only stimulates but also challenges the attitudes and practices of its participants and the community at large. Understanding the state of Detroit and its local population is at the heart of the cultural work that both the 5e Gallery and the Foundation seek to accomplish.

\section{On the Margins of Urban Design}

While zoning laws may not seem like obvious objects of study to grasp environmental conditions

\footnotetext{
${ }^{27}$ See for example, John Connell and Chris Gibson, Sound Tracks: Popular Music Identity and Place (New York: Routledge, 2003); Brian Cross, It's Not About a Salary: Rap, Race and Resistance in Los Angeles (London: Verso, 1993); Anthony Kwame Harrison, Hip Hop Underground: The Integrity and Ethics of Racial Identification (Philadelphia, PA: Temple University Press, 2009); Murray Forman, The 'Hood Comes First: Race, Space and Place in Rap and Hip Hop (Hanover: Wesleyan University Press, 2002); Adam Krims, Music and Urban Geography (London: Routledge, 2007); Ali Colleen Neff, Let the World Listen Right: The Mississippi Delta Hip Hop Story (Jackson: University Press of Mississippi, 2011); Tricia Rose, Black Noise: Rap Music and Black Culture in Contemporary America (Hanover: Wesleyan University Press, 1994).

${ }^{28}$ Forman, The 'Hood Comes First, xvii.

${ }^{29}$ Ibid.

${ }^{30}$ Connell and Gibson, Sound Tracks, 192.
} 
and the state of Detroit, they too shape what can be done on purchased land. It was not until 1940, after twenty-two years of effort, that the Detroit Common Council approved a zoning ordinance. It took nine more years, until 1951, for the city to put a master plan in place. ${ }^{31}$ The city was an industrial leader long before 1940. What is more, environmental protection policy did not exist in Detroit until the mid-1970s. Up until this time companies could build anywhere they deemed productive, despite the proximity of homes, farmland, cemeteries, or water supplies.

These debates continue in Detroit and their effects are as ideological as they are material. They reflect the city's challenge to manage environmental welfare. To understand the politics of environmental protection and sustainability one has to look under the hood of current urban renewal plans to see the spoils. Law Professor Peter Hammer posits a polemical view of the stakes that are tied to Detroit's current trajectory of urban planning. Analyzing the Detroit Future City report-the organization's fifty-year vision for development-Hammer argues that the language and vision of Michigan's blueprint for Detroit is misleading. ${ }^{32}$ In a public lecture about Detroit Future City's vision he stated, "The Detroit Future Plan looks green friendly; however, critical scrutiny reveals that the plan's language is duplicitous." ${ }^{33}$ While Hammer claimed that the city planned to abandon land, the Detroit Future Plan does not make such claims, implicitly or explicitly. Allandra Bulgar, member of the Detroit Future City planning team, explained "We have not provided any concrete plans; we have only articulated a vision that tries to address population loss, civic engagement, and getting more Detroiters employed in Detroit." ${ }^{34}$ In a recent interview, she also explained that in the course of engaging the public "it became clear that the two primary local environmental organizations, Eastern Michigan's Environmental Action Council (EMEAC) and Michigan's Environmental Council, are split over the Detroit Future Plan." 35

Bulgar and Hammer are certainly not the only citizens who have voiced concerns. In 2013, the Detroit Chapter of the Sierra Club published a report on the state of the environment. These authors also question the Detroit Future City's vision, claiming that it misleads residents. They posit, "the basic plan to channel resources toward certain target areas of the city while neglecting others remains intact and

\footnotetext{
${ }^{31}$ June Manning-Thomas, Redevelopment and Race: Planning a Finer City in Postwar Detroit (Detroit: Wayne State University Press, 1997), 36.

${ }^{32}$ Detroit Future City: 2012 Detroit Strategic Framework Plan (Detroit: Inland Press, 2013). While this statement is referred to as a plan, as of yet the document serves only as a vision for urban development.

${ }^{33}$ Peter Hammer, "The Impacts of Detroit Future City" (lecture, Martin Luther King Youth Celebration at the Commons Building, Detroit, MI, January 20, 2014).

${ }^{34}$ Allandra Bulgar, interview by Kellie D. Hay, Detroit, April 11, 2014.

${ }^{35}$ Ibid. Charity Hicks, the policy analyst for EMEAC-Eastern Michigan's Environmental Action Council—explained, "[the problem is that] Detroit neighborhood associations, citizens' groups and community based organizations were not consulted nearly enough, if at all. We have outsiders making decisions for Detroiters, again. Land grabs are rampant. Our voices are not there. Foundations put Detroit Future City together and it is their interests that are being served in this plan." Charity Hicks, interview by Kellie D. Hay, Detroit Commons Building, April 11, 2014. It is worth noting that Hammer's lecture was sponsored, in part, by EMEAC. Other than showing maps that mark population concentrations, he provided no other evidence for his claims, nor did he define the terms that are used in the Detroit Future City's vision. He claimed that the concept of realignment means abandonment. In contrast, Bulgar proclaimed, "There is no language of abandonment in the report, and realignment has not been defined because we have not figured out what it will mean as of yet." Hammer is deeply concerned that realignment will result in lacking investment and care for areas in the city with shrinking populations. He claimed that nearly one quarter of the city's population lives in areas that will be effectively "left alone" without city services or environmental protection. He also singled out six neighborhoods with high population concentrations in addition to Detroit's downtown as sites that are targeted for investment and improvement. His final point was grim. Hammer contends that the vast majority of the city will be left to turn "green." Several times in his lecture Hammer made the point that turning green means the majority of "the city will be wrought with concrete eye soars, wild grass, and weeds." Peter Hammer, "The Impacts of Detroit Future City" (lecture, Martin Luther King Day Youth Celebration, Detroit, January 20, 2014).
} 
fundamentally contradicts the principles of environmental justice." ${ }^{36}$ Along the lines of Hammer's assessment, the Sierra Club report also leads readers to fear the language of urban renewal. The authors worry that the work of Detroit Future City is masking the city's plan to neglect nearly two thirds of the landmass that currently constitutes the city of Detroit. The social, cultural, political, and environmental implications of the city's plan remain to be scene. However, the open question is: does Detroit Future City's plan lead to environmental and social abandonment? The debate has only just begun.

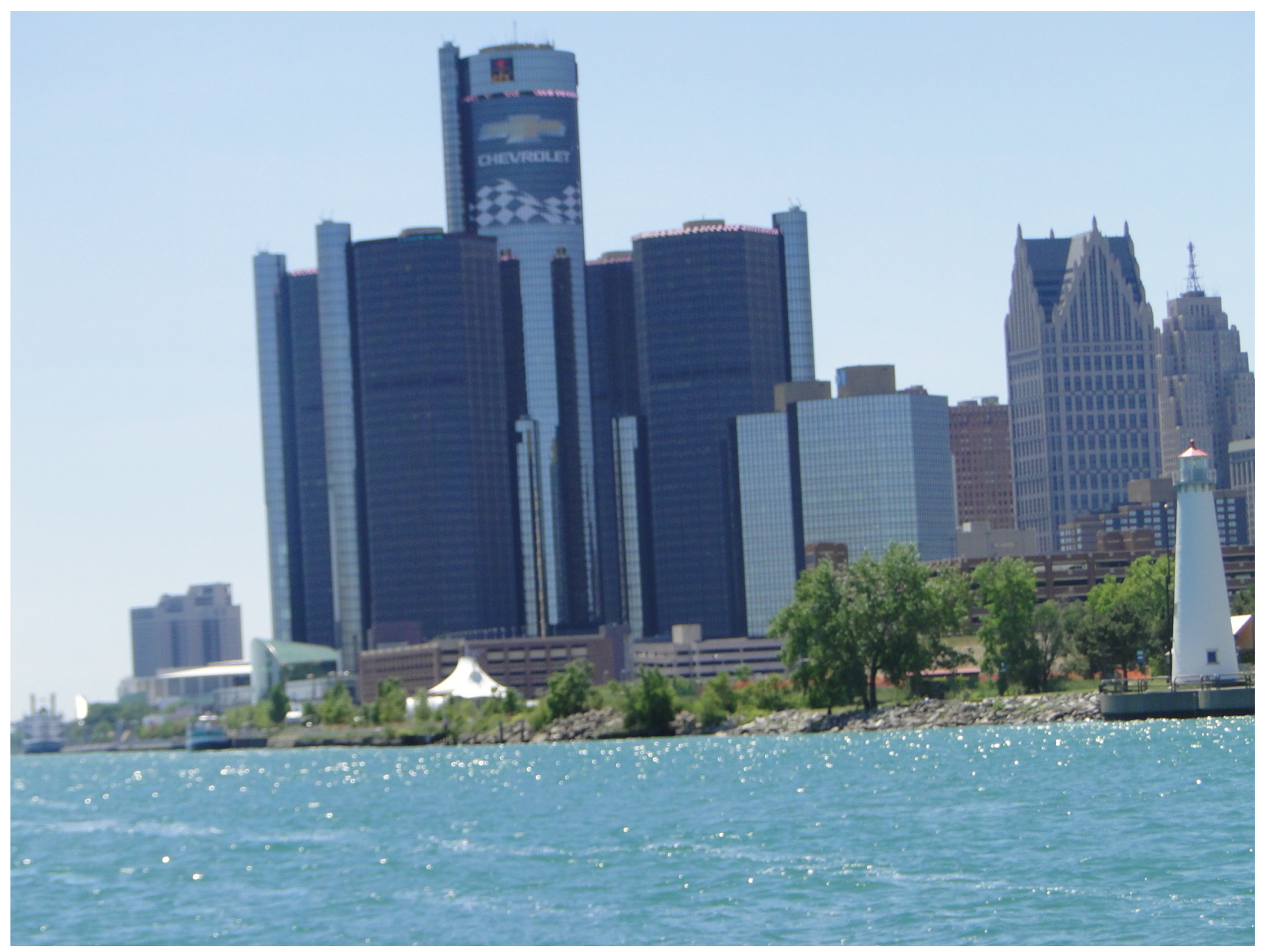

Image 4: GM Towers and Chene Park Ampitheater

\footnotetext{
${ }^{36}$ Sierra Club, "The State of Detroit's Environment: An Initial Assessment Using the Framework of Environmental Justice," accessed December 1, 2013, http://www.SierraclubDetroit.org.
} 


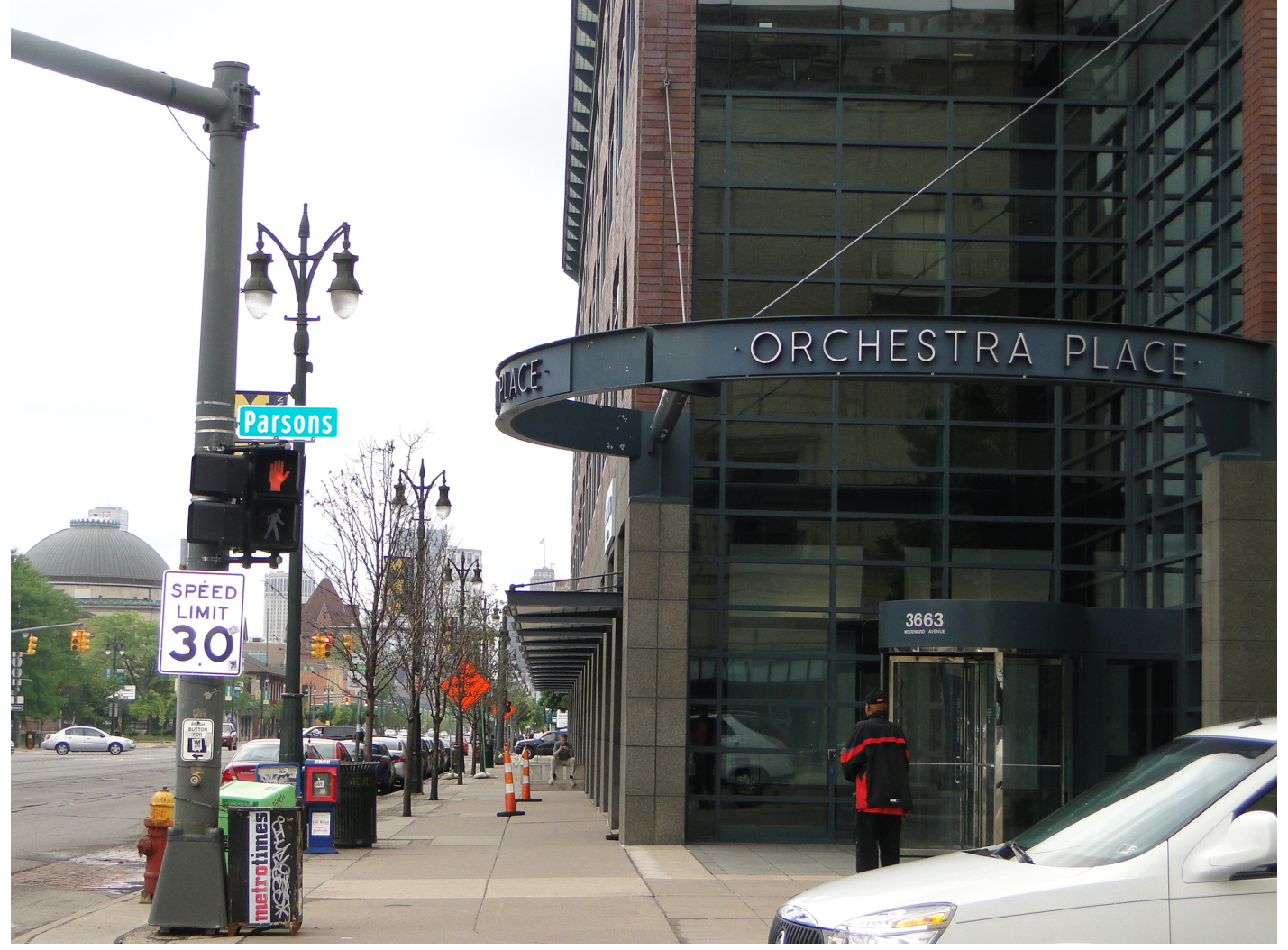

Image 5: Orchestra Hall

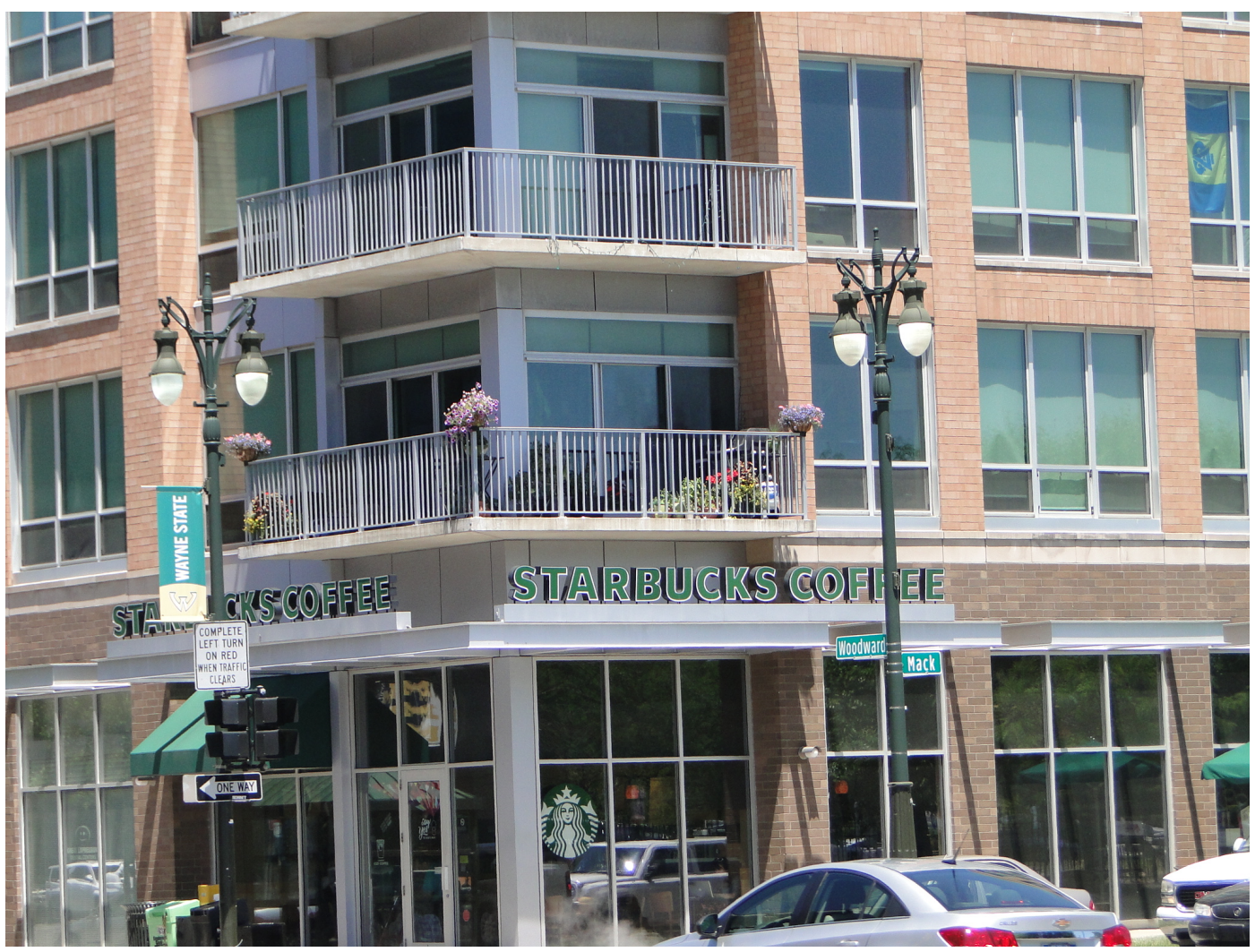

Image 6: Lofts with Starbucks 


\section{Detroit's Contemporary Crises}

Detroit is literally in flux. The city is not only facing environmental threats and economic devastation but also Detroiters are responding to some of the most complex challenges to democracy in the city's history. While all of the impacts are unknown as of yet, the political stakes are clear. The Governor of Michigan has usurped the population's vote by imposing an emergency financial manager, despite an election in which citizens voted to repeal emergency management. ${ }^{37}$ This means more than half a million African American citizens do not have a binding vote in their city, which helps explain why they feel occupied.

Since January 2013, emergency manager Kevyn Orr has been making decisions about how to cut the city's expenses. Thus far, the arts and central sites of recreation have been targets. He attempted to privatize the Detroit Institute of Arts (DIA), the key iconic institution for public art in the city; a move that alarmed citizens. To cut city expenses he also handed Belle Isle over to the state in 2013. Complete with its own botanical gardens, Belle Isle is the city's recreational landmark. As with all state parks, vehicles now have to pay to enter. Prior to this shift, it was a free-to-the-public, popular recreational facility. These decisions affect the costs of recreation; however, Orr's design intensive planning is literally polarizing the population. To cite one example, the owners of the Detroit Red Wings have been granted permission to build a new hockey stadium on residential property. The new building is displacing more than three hundred current residents. It is decisions like these that lead citizens, activists, and other stakeholders to the conclusion that Detroiters feel occupied on a number of levels.

From the perspective of activist Sharon Howell, the massive changes that Detroit is experiencing are the result of its emergency financial management and thus the city is plagued by a state of uncertainty that has left its citizens feeling abandoned, alienated, and occupied.$^{38}$ In the absence of new industry to replace the decline of manufacturing, unemployment is nearing fifty percent, housing conditions are abysmal, the public transportation system is at risk of shutting down, and more than fifteen public schools have closed in the last ten years - the problems are daunting to say the least. Given these conditions, one might expect cynicism, anger, or a sense of hopelessness from the population.

Yet, there have been fascinating, hopeful responses to these changing realities. Currently, the local population is fighting a range of racially marked boundary disputes that bear on urban ecology. These boundary battles are tied directly to food justice. While other cities may struggle with industry or housing encroaching into farmland, Detroit is facing the opposite circumstance. While there is a lack of grocery stores that sell affordable, healthy food in Detroit, there is an abundance of fertile land ideal for local farming. ${ }^{39}$ As a result, people have turned to do-it-yourself strategies for growing their own food and raising animals such as chickens and sheep within the city's limits. Anyone who ventures into the Cass Corridor, Hyland Park, or Detroit's East Side is privy to these movements. Investors claim that livestock in

\footnotetext{
${ }^{37}$ In 2012 voters in Detroit successfully repealed the governor's right to impose emergency managers on cities on the brink of bankruptcy. Within weeks after the election, the Snyder administration created law that preempted voters from repealing emergency managers. What is more, the new legislation shifted emergency managers to emergency financial managers. This change in language gave managers the power to usurp city councils and all other elected officials within the city, including the mayor and the chief of police. Several other cities in the state are also under emergency financial management including Pontiac, Benton Harbor, Hyland Park, and Taylor. It is worth noting that all but one of these cities is predominantly black. ${ }^{38}$ Sharon Howell, "Week 18 of the Occupation," The Michigan Citizen, November 29, 2013, http://www.michigancitizen.com/emerging-future.

${ }^{39}$ Kevin Peterson, "Room to Grow: Detroit Takes the First Steps to Legalize Urban Agriculture," Michigan Journal of Environmental and Administrative Law, February 8, 2013, http://students.law.umich.edu/mjeal/2013/02/room-to-growdetroit-takes-the-first-steps-to-legalize-urban-agriculture.
} 
residential and business areas will harm profit and disturb citizens. These practices have also disrupted the plans of city officials. While locals push for urban farms, the right to raise livestock, and alternative transportation, urban planners are imagining cool cities designed to create business centered around leisure activities, such as hipster restaurants, chic music venues, museums, boutiques, public art, and landscapes so crafted that they appear artificial. ${ }^{40}$

The urban planning in Detroit is parallel to what Adam Krims theorizes as "design intensity." According to Krims, "the term refers to the tendency in advanced societies for products and services to owe much of their value to aspects of design and informational content, and informational aspects of products and services to develop rapidly." ${ }^{\prime 1}$ From this perspective, today's design is based in new information technologies. In post-Fordist cities, new technologies are central, as the service industry and highly computer-based leisure practices have replaced manufacturing modes of production. Computer software companies sprawl out and nestle into cool cities. Krims turns to Silicon Valley in the south San Francisco Bay area and Microsoft and Intel in Seattle to demonstrate the intricate ways in which culture is built around industry, and vice versa. Design intensity explains the trend toward concentrated cultural regeneration, in the form of industries built around leisure practices like concerts, clubs, fine dining, arts, and theater districts. The planning is highly privatized; that is, corporate conglomerates have influence in designing space - the centers and routes of business - in as much as they have a stake in their product design. ${ }^{42}$ BCDs (Business Centered Districts) are designed to host a constellation of leisure, consumption, and tourism industries. Young, single, educated, well-paid workers are encouraged to participate through cultural and financial investments: personal services, salons, spas, hotels, restaurants, parks, historical promenades, amphitheaters, multiplex cinemas, and arenas.

If these are the markers of the design intensity of contemporary cities, the questions then become who benefits from design intensity and what role does music play in urban design? For Krims, city planners play a role but corporate conglomerates have the most influence, in terms of not only access but also sponsorship. ${ }^{43}$ He uses post-Fordist neoliberalism to explain the shift from government-sponsored to privatized, corporate-controlled urban planning. It is no accident that elite musical sites like opera houses and symphonies are located in downtown city landscapes nestled among expensive restaurants, sports stadiums, and other culturally privileged places. These places are highly policed and regulated. They are designed for professionals who have upwardly mobile careers and lifestyles. Detroit's residents are predominately black, and while many of them work in the city's service industry, at the day's end most travel to the outer regions of the city and dwell in dilapidated conditions. The city's revenue flows into design-heavy business centers and away from the polarized population living in Detroit. Working-class people of color often feel out of place in Detroit's design-intensive sites. In response to their marginalization, Detroiters have created a rich culture of alternative and underground sites where creative energy flows back and forth. Here, Detroiters respond to the challenges they face with polarized residence and cultural imagination.

The 5e Gallery is one site that provides marginalized populations with a safe space to create art and

\footnotetext{
${ }^{40}$ Sharon Howell, interviewed by Kellie D. Hay, Detroit, MI, September 18, 2013. The press is not reporting on these tensions. According to Sharon Howell, the debates are taking place in neighborhood association meetings, town meetings, and city council meetings. After attending more than twenty of these meetings, she explained the conflicts between stakeholders: residents, city planners, neighborhood associations, and city officials.

${ }^{41}$ Krims, Music and Urban Geography, xxix.

${ }^{42}$ Ibid., xxviii.

${ }^{43}$ Ibid., 12.
} 
community, ${ }^{44}$ and the Foundation, based at the gallery, is Detroit's only hip hop collective committed to creating a stage for socially conscious women hip hop artists and supporters. Since 2009 the Foundation has hosted a weekly open-mic event that features women poets, musicians, MCs, B-girls, ${ }^{45}$ graffiti artists, and activists committed to creating healthy places for women in hip hop. ${ }^{46}$ While the Foundation celebrates the contributions of women to hip hop music and culture, its parent organization the 5e Gallery supports artistic growth and community engagement for men and women in a cross-racial, multigenerational context. Since 2012, we the authors have been active participants in the collective, attending weekly events and meetings. From our perspective, the Foundation is both a site of research and a ground for engineering progressive social change. Detroit's environmental, social, economic, and political issues play a vital role in the Foundation's work. Most of the artists have strong ties to Detroit and/or currently live in the city. Its history, contemporary state, and future possibilities are articulated in the music, music videos, visual arts, and other creative projects produced here. In addition to their artistic endeavors, members of the Foundation are also involved in youth activism, mentoring, and other tactics focusing on reimagining a more culturally sustainable and socially and politically balanced city.

\section{Imagining and Producing "Legendary"}

In 2013 we collaborated on a track and video with the Foundation artists for the Ecomusicology Listening Room session at the annual American Musicological Society conference in Pittsburgh, Pennsylvania. The call for submissions was discussed only briefly with Foundation members to the extent that those involved agreed that the final product—a music video-should address the multilayered dimensions of marginalization that Detroiters experience. We wanted to address both the place of women in Detroit's hip hop scene and the areas in the city that have been demolished or abandoned. The abandoned spaces that have become so prevalent continue to have lasting effects on the city's human, cultural, and political environment. After our brief issue-storming conversation, it was left to the two participating MCs, Mahogany Jones and 'Nique LoveRhodes, to make sense of these ideas as they wrote the verses and refrain for the song. Piper Carter, co-owner of the 5e Gallery and founder of the Foundation, worked on the project as videographer and editor. The authors' efforts were mainly focused on working with Piper to develop the concept for the video and to assist with production on shooting day. Prior to meeting in person to discuss the video concept we shared our interpretations of the track's lyrics over email. Jones's frequent producer IRonicLee created the beats that she and LoveRhodes chose for the project. In an interview that Mark Pedelty conducted with the Foundation members at the AMS conference, Jones described the beat as "blue color, grinding . . . [with] this pulse in it that feels hopeful." 47 LoveRhodes added, "there's a certain spirit in instrumental tracks that pulls out certain things. This is

\footnotetext{
${ }^{44}$ It is self-described as "an alternative multi-disciplinary arts organization that presents and supports contemporary artists and their work, facilitates the creation of new work, and creatively engages, builds, and informs audiences and communities." 5e Gallery website, accessed May 12, 2014, http://5egallery.org/about/.

${ }^{45} \mathrm{~B}$-girls are female breakdancing practitioners.

${ }^{46}$ In 2009, Piper Carter returned to Detroit due to her mother's illness, leaving behind a well-established career as a fashion photographer in New York City. In our interview she recounted her love for and long history with hip hop and the strong presence of women in New York City's hip hop scenes. In New York Piper immersed herself in a rich culture of hip hop, where women were actively involved. Frustrated with the lack of women, both on and off the stage, at Detroit hip hop events Piper was inspired to start the Foundation. Piper Carter, interviewed by Rebekah Farrugia and Kellie D. Hay, Detroit, MI, January 14, 2012.

${ }^{47}$ Mahogany Jones, interview by Mark Pedelty, November 9, 2013, American Musicological Society, Pittsburgh, PA.
} 
revolutionary and we're revolutionaries so we're gonna tell you how we feel." 48 The beats and larger messages within "Legendary" hearken back to a time in hip hop when the vocal command of women was more socially conscious and openly political.

In her influential book Black Noise, Tricia Rose provides a foundational look the musical output of the first generation of black women rappers in the 1980s and early 1990s. In her analysis Rose argues that while male and female rappers have a lot in common, the subject matter expressed by women was different from that of their male counterparts. Because of their sexually progressive, antisexist voices, black women were "heralded as rap's politically correct underdogs." characterized the work of black women rappers in the 1980s were "heterosexual courtship, the importance of the female voice, and mastery in women's rap and black female public displays of physical and sexual freedom." ${ }^{50}$ This attention to sexual politics steadily declined beginning in the mid to late 1990s with the breakthrough of artists such as Da Brat, Lil' Kim, Foxy Brown, and Eve. Their song content and stylistic approach paralleled that of the male gansta' rappers who were gaining popularity through emphasis on financial wealth, survival in the 'hood, and fighting ability.

Building on the work of early artists such as Queen Latifah, MC Lyte, and Salt 'N' Pepa, Rose makes visible the political agency early women rappers were able to attain. Writing in the early 1990s, Rose could not have imagined today's hip hop market. By the end of the decade major record labels were no longer signing deals with the type of MCs who were commercially successful in the 1980s. The hypersexualization that exists now was not yet the dominant trope or tactic governing hip hop's cultural production. Not only do the women of the Foundation recognize the "video vixen" subjectivity ${ }^{51}$ that dominates contemporary commercial hip hop, but the collective also battles to create anew the political agency that early rappers had the power to produce. The work of the Foundation, and "Legendary" in particular, comments on the politics of place, which heretofore has not been fully articulated in women's rap music. "Legendary" is about women taking a stance on their political surroundings, their physical environments, and their responses to these conditions.

The first verse, written and performed by Jones, is ripe with historical references to racial injustice (see appendix). The words "the constructs created" can be linked to what George Lipsitz calls "the possessive investment in whiteness." ${ }^{2}$ He tracks the materiality of white privilege in the form of housing policies and unequal access to loans that kept whites and blacks divided in urban centers and suburban "white flight" expansion. Many of Detroit's housing developments from the 1920s through the 1960s had covenants attached to them stipulating that only white residents could purchase property or rent. ${ }^{53}$ The history of whiteness has reproduced itself in contemporary Detroit. This verse speaks also to contemporary life where taxes are high but social services, police, and emergency medical "response time is slow." The structures have not radically changed from the 1940s, when housing developments were

\footnotetext{
${ }^{48}$ 'Nique LoveRhodes, interview by Mark Pedelty, November 9, 2013, American Musicological Society, Pittsburgh, PA.

${ }^{49}$ Rose, Black Noise: Rap Music and Black Culture in Contemporary America, 147.

${ }^{50}$ Ibid.

51 "Video vixen" is a term used to describe hypersexual, attractive women who appear in hip hop videos. They are often actors taking on the role of strippers.

${ }^{52}$ George Lipsitz, "The Possessive Investment in Whiteness: Racialized Social Democracy and the White Problem in American Studies," American Quarterly 47, no. 3 (Autumn 1995): 371.

${ }^{53}$ For extended discussions of race and housing see, Thomas Segrue, The Origins of the Urban Crisis: Race and Inequity in Postwar Detroit (Princeton: Princeton University Press, 1996) and Karen A. J. Miller, "Living in the Arsenal of Democracy: Workers and the Problem of Housing," paper presented at the North American Labor History Conference, Wayne State University, Detroit, MI (October 2012).
} 
legally zoned to separate whites from blacks and the police were perceived as a threat to black populations rather than a source of safety. The feeling that no one cares about "my whereabouts as long as I'm St. Elsewhere" conveys the sentiments of abandonment. These lines illustrate the ways in which Detroit residents feel invisible to the surrounding populations who govern them.

Jones also catalogues the uninvited rebellion of $1967 .{ }^{54}$ In her words, it took a bloody uprising to change the course of history in Detroit and still the city has not recovered; the improvements that followed did not come from liberal reform. Much of the progressive change has emerged from local communities and activist organizations including the Foundation, Detroit Summer, and the Boggs Center. The Paradise Valley that Jones references was an entertainment zone-home to jazz and blues clubs, salons, soul food restaurants, and churches-that was part of the Black Bottom district. The neighborhood was home to the city's African American entrepreneurial class. ${ }^{55}$ This thriving black community was desolated in 1964 so that a freeway could be built in its place. Jones bemoans this destruction and calls into question the iconic imagery that was also lost. ${ }^{56}$

The refrain (or hook) provides a sense of optimism to the track. "Doves cry / But we gonna jump up off the ledge and fly / Cuz real legends never die." In a recent interview with Mark Pedelty, Jones commented on the importance of perseverance amidst the industrial decline in Detroit. "Yes it hurts, yes we cry. But real legends never die. Legends live on. Our city lives on. Women, we do great things, we live on with the work that we do whether celebrated or not celebrated." ${ }^{" 57}$ When the Foundation responded to questions on the AMS panel, Jones made a similar observation. "Detroit is like a bad marriage. In the course of the relationship the wife becomes sick. Instead of helping, the husband simply leaves." 58 Jones brings home the point that although regeneration and investment are missing, Detroiters are still creating new ways to survive.

In verse two, LoveRhodes sees unusual hope coming from unloved places. Located within her own subjectivity, she likens a woman's beauty to the grittiness of a neglected city. Beauty is connected to blackness, womanhood, and strength, even when it appears otherwise. She asks listeners to think about unanticipated growth, life coming from underneath "the concrete where it ain't supposed to happen." This is a metaphor for the resilience of Detroiters. She speaks spirit in the ability to improvise with those "lemons that make lemon pie." Detrotiers are accustomed to doing more with less. This statement

\footnotetext{
${ }^{54}$ Mahogany Jones elected to use the word "riot" within "Legendary"; however, we purposefully employ the term "rebellion." Detroit activists Jimmy Boggs and Grace Lee Boggs contend that rebellion is not simply reactive resistance on the part of unruly people going wild; but rather is tied to an ethic of social change, one that is conscious and incremental. In the revised introduction to Revolution and Evolution in the Twentieth Century, Grace Lee Boggs explains that riot, according to the mainstream media, refers to a simple breakdown in law and order. "A rebellion, we decided, is an important massive uprising and protest of the oppressed. Therefore, it not only begets reforms but also throws into question the legitimacy and supposed permanence of existing institutions." From Grace Lee Boggs's perspective, the concept is only a stepping stone, an intentional set of tactics that leads to a broader revolutionary practice. James Boggs and Grace Lee Boggs, Revolution and Evolution in the Twentieth Century(New York: Monthly Review Press, 2008): viii.

${ }^{55}$ John Gallagher, "When Detroit Paved Over Paradise: The Story of I-375.” Detroit Free Press, December 15, 2013, accessed April 17, 2014, http://www.freep.com/article/20131215/OPINION05/312150060/Black-Bottom-Detroit-I-375-I-75-paradisevalley-removal.

${ }^{56}$ Young people of color in the Bronx, New York, had a similar reaction to the construction of the Cross-Bronx Expressway, which displaced tens of thousands of people of color in the 1960s and 1970s. In response to the condemnation of the affected neighborhoods, young people created cultural outlets of expression and built their own cultural networks. One evolution of these practices was the birth of hip hop music and culture. For further discussion, see Jeffrey O. G. Ogbar, The Hip Hop Revolution: The Culture and Politics of Rap (Wichita: University of Kansas Press, 2007): 3-5; and Rose, Black Noise, 31. ${ }^{57}$ Mohogany Jones, interview by Mark Pedelty, November 9, 2013, American Musicological Society, Pittsburgh, PA.

${ }^{58}$ Mohogany Jones, addressing questions at the Ecomusicology Listening Room session at the Annual Meeting of the American Musicological Society, November 8, 2012, Pittsburgh, PA.
} 
captures the essence of a common, local slogan "Detroit Hussels Harder."

LoveRhodes also makes clear that people around the globe have their eyes on Detroit. It is a model for urban farming and the repurposing of technology and space for alternative ways to create new working environments. Work and race are indelibly linked. Detroit's population is 81 percent black, yet three out of four people who live in Detroit work outside the city. This means that the majority of black residents cannot find work within the city. In response, LoveRhodes chooses to emphasize the positivity of repurposed black identity. Without pause she brings race to the fore in a proud, hopeful style. "You can't take black out of beauty" is one truism. The idea that marginalized populations are motivated by "pride, spirit, and soul" opens a way to rethink what is possible in the city and it does so significantly from the perspective of African American women. LoveRhodes's verse exemplifies an intersectional theory of identity formation. ${ }^{59}$ Her statements provide crossroads. They have the ambiguity that allows for forks in the road, as well as a forged sense of urban identity and community. The multidimensional identity claims that emerge in the lyrics of "Legendary" led us to conceptualize the geographical locations that would match the sentiments addressed within the song.

Once the song was written we moved on to conceptualizing the scenes that would constitute the video. Piper Carter astutely led us to our shooting locations. To reflect neglect, dilapidation, and pollution (the general abandon referenced in Jones's verse), we chose a closed, run-down community center. Behind it sits an old swimming pool, tagged with graffiti and containing stagnant, murky water. As we talked about positive imagery, bright spots, and creativity, we chose three brightly painted murals as backdrops for LoveRhodes's verse. These murals carry a deep significance because of their location in the Cass Corridor-an area of the city that has been an active artistic neighborhood since the 1960s. Additionally, we agreed on capturing footage of an urban farm (Spirit Farm, also located in the Cass Corridor) to show the resourcefulness of people who are creating their own food supply. We also shot driving scenes to use as transitions between locations. The juxtaposition of sustainable urban farms and large, oil-reliant vehicles reflects the contradictions of living in a city where buses are the only form of mass-transit; riders commonly wait hours for service. Motor City's stake in the people's heavy reliance on automobiles is not just a rhetorical jingle; with Krims in mind, this is a design-intensive construct which leaves out those who quite literally cannot afford to buy into the system. The additional supplemental footage we used to intercut between the performance video invites viewers to perceive the relationship between history, abandonment, and rejuvenation. This is especially important for black women because the concerns of people of color are often overshadowed in environmental and social justice debates. As Rose Gray points out in her review of "red, black \& GREEN: a blues (rbGb)"-a hybrid theater piece that explores significant roadblocks to black environmentalism- "environmentalism is often considered a privileged, white concern." "Legendary" demonstrates black women's political agency and publicizes their commentary about the conditions in which they live. While the video does not showcase literal imagery of smoke stacks polluting the air, declining water tables, or other explicit signifiers of environmental catastrophe, it does illustrate the effects of abandoned land, desolated neighborhoods, and concrete eyesores. In Detroit, African Americans have taken the lead on environmental action. It is notable

\footnotetext{
${ }^{59}$ Intersectionality is a sociological theory of identity that suggests that categories such as race, class, age, sexuality, and gender all intersect and bear on identity formation. In the context of feminism and hip hop, see Patria Hill Collins, Black Feminist Thought: Knowledge, Consciousness, and the Politics of Empowerment (New York: Routledge, 2000 ): 66-67. ${ }^{60}$ Ross Gray, "Red, Black, and Green: A More Inclusive Environmental Movement Takes the Stage," Orion Magazine, March/April 2014, accessed April 6, 2014, http://www.orionmagazine.org/index.php/articles/article/8050.
} 
that women of color are in leadership positions in the Detroit offices of two pivotal environmental organizations-Eastern Michigan Environmental Action Council and Michigan's Environmental Council.

When asked how they thought this music video might have been similar or different if it was about marginalization elsewhere, the artists firmly answered that the track and video are unique to Detroit. LoveRhodes explains:

I think this is the beauty of music that people can find their story in something that's totally unrelated. So maybe if somebody saw this video and said "oh this is a great video about Detroit," but they can still find the commonality; like I grew up in a marginalized community on the south side of Chicago. Let me research why it is that way. ${ }^{61}$

Thus, the specificity of the lyrics and video images along with their indisputable references to Detroit is a purposeful political move employed to explain the current state of Detroit and the complex relationships that residents have to the city. The video also seeks to motivate individuals and whole communities to rise above current conditions and in LoveRhodes's words "make something out of nothing." Such calls to action are vital to improving local conditions-environmentally, culturally, socially, and psychologicallybecause leaving is not a simple or easy option for many. In their research on the role of local politics in the restructuring of local economies in the United States, Kevin Cox and Andrew Mair observe that there is a material basis for people to be locally dependent. ${ }^{62}$ With only one in four residents employed in the city, housing that is either inaccessible or unaffordable, and schools that are failing the public, the resources and job allocation available to Detroiters can neither provide sustenance nor create conditions for new ways of imagining work. When welfare support, unemployment payments, and delinquency climb, as they do in Detroit, dependency remains a structural problem.

Additionally, in a context where urban spaces are gendered male, this video serves as an example of how music can be used to challenge gendered power dynamics in a manner similar to how women blues singers of the 1920s and 1930s explicitly addressed the contradictions of feminism, sexuality, and power in their music. The work of the Foundation builds on the socially conscious discourse of the classic blues, which articulates a cultural and political struggle over sexual relations, ${ }^{63}$ to also include commentary on public space and environmental sustainability. Connell and Gibson argue that much of the media created within hip hop reflects a "symbolic reclamation of the city." ${ }^{44}$ The list of names of groups, albums, songs, and films they include as examples all refer to the cultural productions of men. Aware of men's domination of geographical and musical space they comment, "geographical space is inherently embroiled in gender politics. Space carries within its form the dominant ideologies and politics that, in respect to gender and sexuality in the realm of music, remain overtly conservative, patriarchal and heterosexual." ${ }^{\prime 65}$ Consequently, women—let alone queer and transgendered communities—have been all but shut out from engaging in this dialogue and commentary on social location and identity in hip hop. Thus, it is significant that it was a collective of women who conceptualized and produced the track (except for the beats) and video for "Legendary." The women-centered nature of this production openly resists the gender dynamics that are present not only in hip hop culture but also in broader conversations related to space and

\footnotetext{
${ }^{61}$ 'Nique LoveRhodes, interview by Mark Pedelty, November 9, 2013, American Musicological Society, Pittsburgh, PA.

${ }^{62}$ Kevin R. Cox and Andrew Mair, "Locality and Community in the Politics of Local Economic Development," Annals of the Association of American Geographers 78, no. 2 (June 1998): 313.

${ }^{63}$ Hazel V. Carby, "It Jus Be's Dat Way Sometime: The Sexual Politics of Women's

Blues," in The Jazz Cadence of American Culture, ed. Robert O’Meally (New York: Columbia University Press, 1988$): 474$.

${ }^{64}$ Connell and Gibson, Soundtracks, 85.

${ }^{65}$ Ibid., 209.
} 
environmental sustainability. First of all, it is interventionist that women are telling a political story entrenched in the politics of space and place. What is more, the video illustrates women in multiple subject positions: as protesters, mothers, farmers, and musicians. These are not the depictions that one finds in contemporary, commercial hip hop. It is not commonplace in mainstream hip hop to see or hear women contesting political and physical ruins. Breaking away from the hypersexualization of women is productive on its own terms. The narrative encourages positive responses to hopeless conditions. The dominant subjectivity produced by this music is unlike that of men-centered rap music. There is no violence offered as a viable answer; the typical representations of men toting guns and glorifying sex and money do not surface. The rarity of the presence of African American women's perspectives and voices in these discussions, let alone as the focus of related scholarly work, should not be underestimated. ${ }^{66}$

Indeed, the politics of representation are at stake in "Legendary." Pushing the limits of discourse, Krims sees representation as one force among many that affect cultural regeneration. Krims captures the scope and temporality of urban respresentations through the concept of urban ethos. The urban ethos is not a representation per se but a distribution of representations that operates as a discourse. Using rap music and music videos as a way to interpret contemporary post-Fordist conditions "in the 'hood," Krims sees the urban ethos as a web, constituted through institutional actors creating blogs, music, music videos, Internet content, and television programs, among other media texts. When all of these outlets expose the same sensibility about urban space the ethos becomes identifiable; in other words, the distribution of representations has done its work.

"Legendary" is constituted in a reconfigured urban ethos distinct from Krims's conception. For Krims, gender relations are polarized in urban space. In the 'hood, he uses rapper 50 Cent as the example of violent hegemonic masculinity. The 'hood is one side of the polarity and is more male. The city, however - as signified by the amorphous sounds of Petula Clark's "Downtown"-feels softer and safer. As such, race is unmarked and the sounds of downtown space are imbued with more female sensibilities. "Legendary" does not construct either/or binaries with respect to gender identity and urban space. Instead, it depicts physical and social abandonment, the traces of racism that has divided neighborhoods, and police blocking protestors with bobby sticks and shields. Overwhelmingly, male-dominated commercial hip hop combats racism and police brutality through an eye-for-an-eye mentality where violence begets violence. These are the practices that Krims addresses in his claim that the 'hood is male. The artists who produced "Legendary" complicate Krims's binary. Their lyrics and imagery are interpretations of both the history and the contemporary issues that Detroiters face. However, contrary to Krims's view, women do not simply embody the sanitized aesthetic of downtown spaces. Here, we see women all over the city taking on roles in the public sphere that are often relegated to men.

The artists are rapping from a woman's perspective that nevertheless intersects with race, city, and place. The rapid images demonstrate the dilapidated brokenness that Detroiters face, but they also point to hopeful, creative, and spirited movements citizens are launching despite having meager resources. Krims does not imagine gendered space outside of the polarizing effects of design intensity, but "Legendary" redesigns what city and place mean when women have vocal and visual command.

\footnotetext{
${ }^{66}$ Rosenthal, "'Hoods and the Woods," 667. To be fair, Rosenthal's choices reflect the male dominated hip hop music industry. If there were women making ecologically conscious hip hop in underground scenes at the time it was (and continues to be) rare for such artists to gain widespread recognition. Even in her analysis of environmentally conscious hip hop Rosenthal features male rappers exclusively.
} 


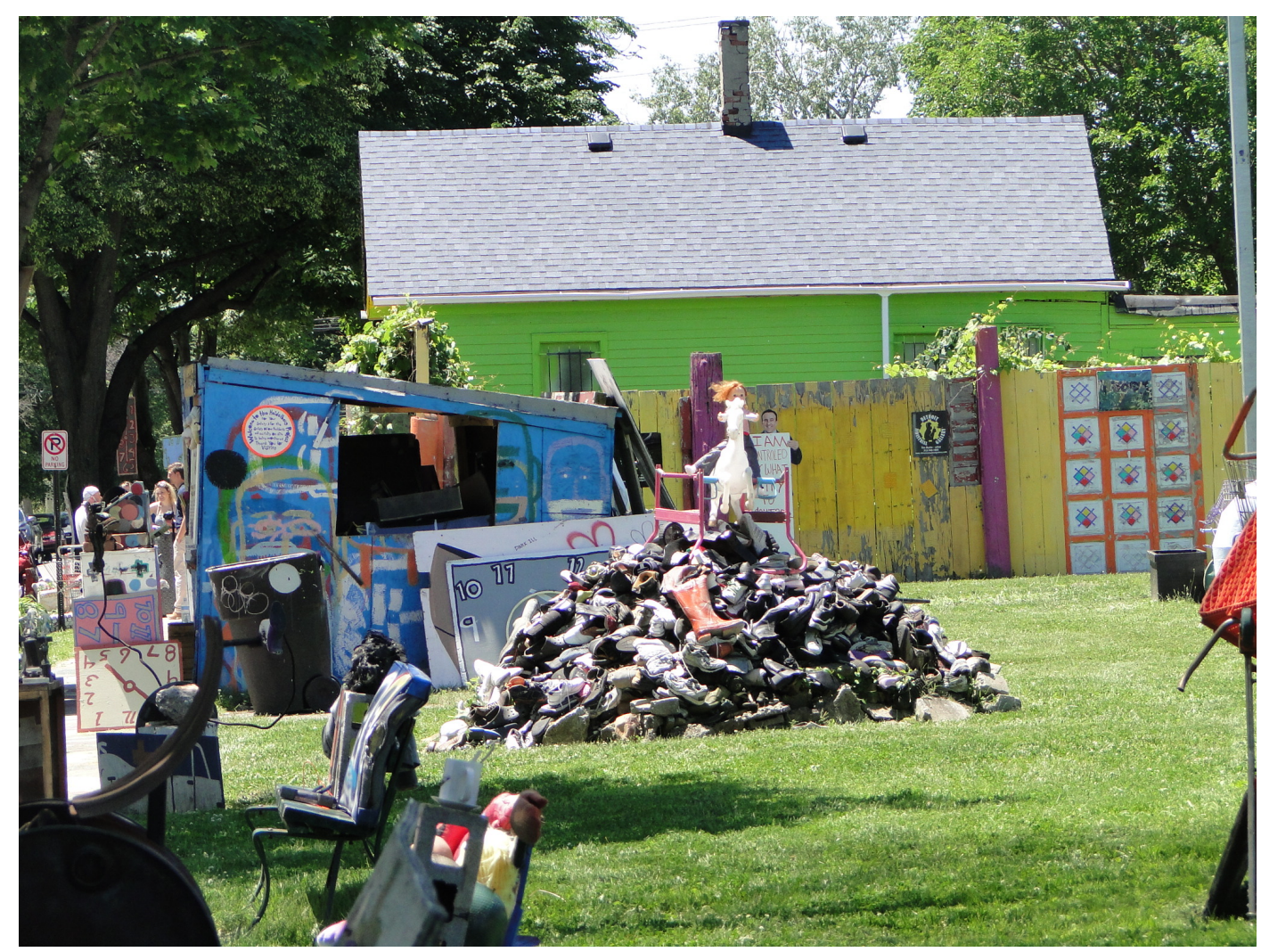

Image 7: Heidelberg Project

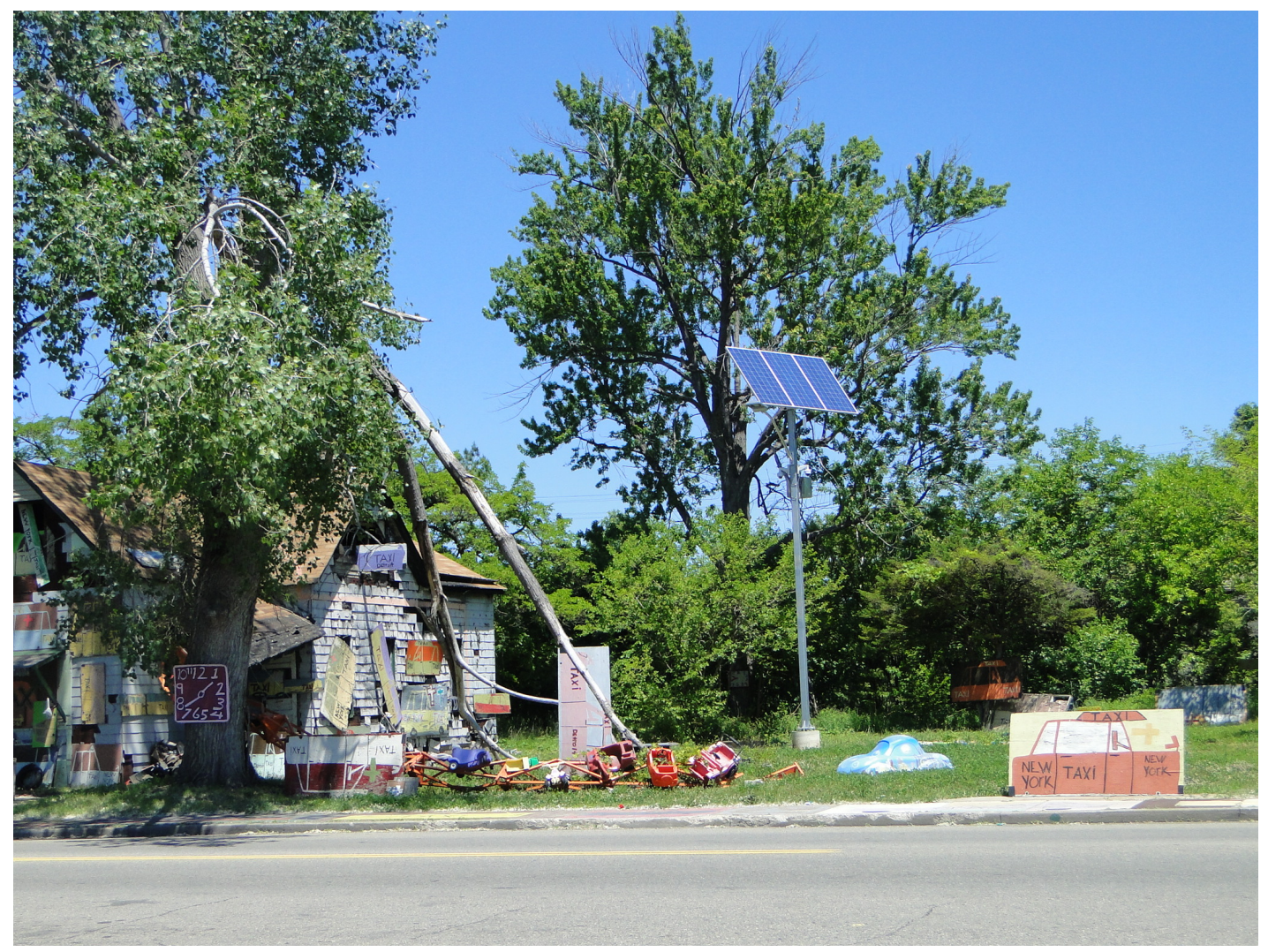

Image 8: Heidelberg Project with Solar Tower 


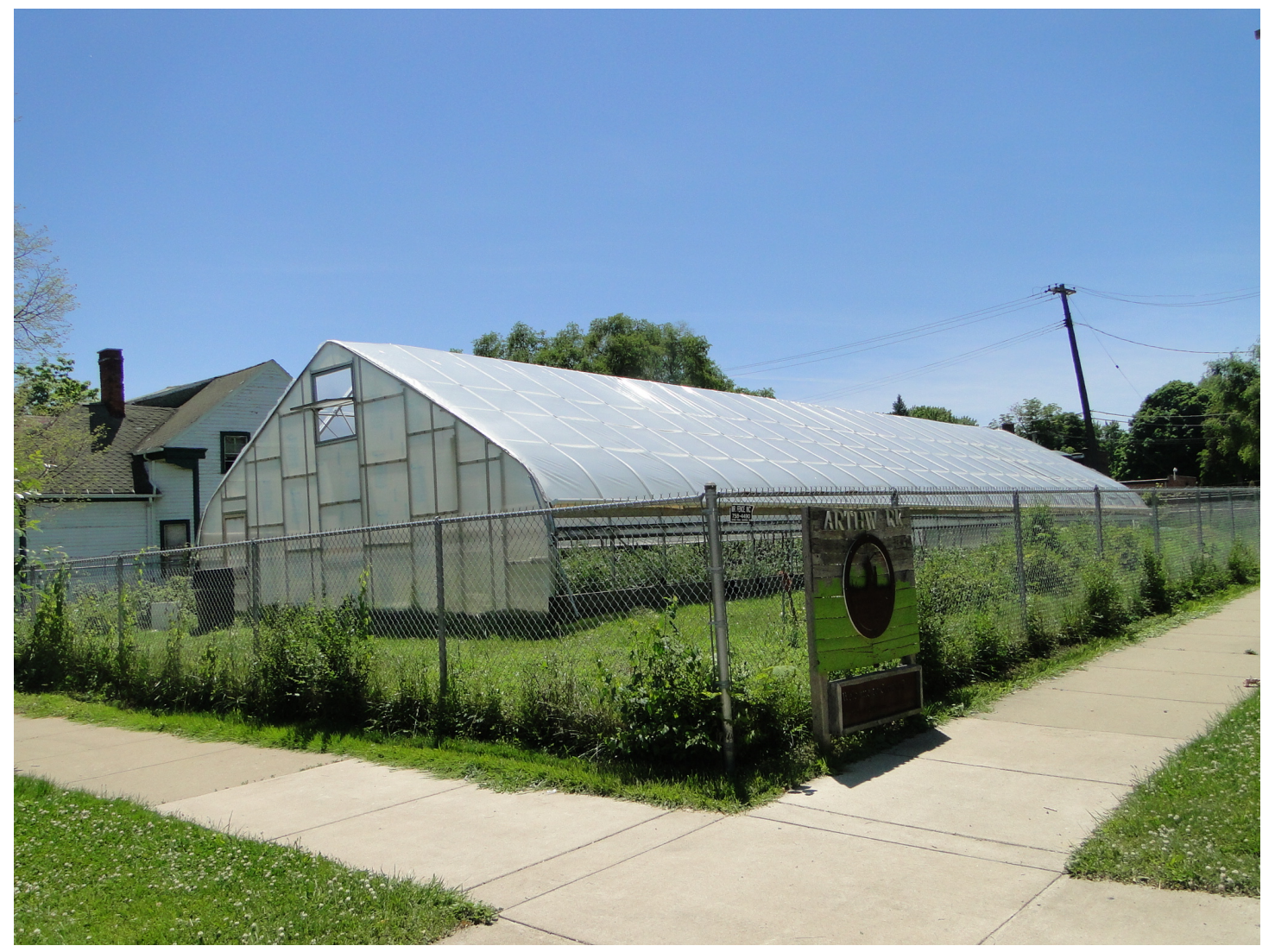

Image 9: Earth Works Urban Farm

\section{Conclusion: Reclaiming Agency}

"Legendary" and the process of its production tell a story about collaboration, alienation, and the reimagining of space in a place that is primarily defined by racism, deindustrialization, and displacement. Recent ecomusicological studies have observed the powerful role that music plays in challenging and reimagining contemporary environmental, social, and political conditions. Pedelty clearly addresses the symbiotic relationship between music and the environment. On the one hand, he stresses that people, places, and technologies generate songs; on the other, "music helps us define who we are and mediates our imagination of place. ${ }^{97}$ In other words, music can serve as a vehicle for understanding our sense of self and opening up possibilities for the kinds of communities in which we want to live. For the most part, mainstream media representations of Detroit replicate narratives of dilapidation and disparity; rarely do they acknowledge the work of vital, resilient citizens, DIY organizations, and underground art and culture. Yet in reality these collectives are responsible for generating provocative ideas about the repurposing of space and technology, creating and maintaining an urban farms movement, and forcing urban planners, politicians, and corporate-sponsored foundations to take neighborhood associations seriously. What we offer in "Legendary" opens space for conscious, collaborative, interventionist work that poses new questions for ecomusicological inquiry. ${ }^{68}$

\footnotetext{
${ }^{67}$ Pedelty, Ecomusicology, 12.
}

${ }^{68}$ Folk musicians, such as Woody Guthrie, Bob Dylan, and Peter Seeger, wrote music that aimed to open up spaces for listeners to think about the relationship between the self and the kinds of community these artists envisioned. Hip hop is a 
In "Legendary," resilient African American women draw attention to issues and experiences tied to racism and marginalization through vivid imagery of dilapidation and loss. However, unlike the messages most commonly represented in commercial hip hop, the Foundation offers solutions to these societal ills. "Legendary" provides viewers with a different understanding of the city, one that is gendered female and encourages positive solutions rooted in creativity, strength, and solidarity. This work disrupts the polarity that Krims proposes, of the 'hood as male and the city as female.

The writings of Detroit-based social justice activist Grace Lee Boggs in part motivated us to seek out and create musical texts with socially conscious hip hop artists. Boggs has been living in Detroit and documenting the ongoing struggles of the city's residents for more than half a century. In her most recent book she calls for visionary organizing, which begins by "creating images and stories of the future that help us imagine and create alternatives to the existing system." ${ }^{69}$ As we state in the beginning of this paper, hip hop culture and rap music in particular were born out of the struggles and experiences of people of color in the South Bronx in the late 1970s. Since this time, struggles related to deindustrialization and racism in Detroit have intensified.

Our goals with the production of "Legendary," as well as the documentation of the process and our reflections on it, have been twofold. On the one hand, this work demonstrates the role that music can play in reimagining space and place. On the other, following Boggs, it encourages the vision of new, more participatory place-based concepts of citizenship and democracy. Citing organizational behavior expert Margaret Wheatley, Boggs powerfully argues, "movements are born of critical connections rather than critical mass." ${ }^{70}$ The academic and artistic connections presented here were vital to the vision and production of "Legendary" and the musical and environmental movements that such musical texts inspire.

\section{Bibliography}

Adam, Tony E. "Speaking for Others: Finding the 'Whos' of Discourse." Soundings: An Interdisciplinary Journal 88, no. 3/4 (Fall/Winter 2005): 331-45.

Alcoff, Linda. "The Problem of Speaking for Others." Cultural Critique 20 (Winter 1991-92): 5-32. http://dx.doi.org/10.2307/1354221.

Allen, Aaron S. "Prospects and Problems for Ecomusicology in Confronting a Crisis of Culture." Journal of the American Musicological Society 64, no. 2 (Summer 2011): 414-24. http://dx.doi.org/10.1525/jams.2011.64.2.414.

Attali, Jacques. Noise: The Political Economy of Music. Translated by Brian Massumi. Manchester: Manchester University Press, 1985.

Boggs, James, and Grace Lee Boggs. Revolution and Evolution in the Twentieth Century.New York: Monthly Review Press, 2008.

Boggs, Grace Lee, and Scott Kurashige. The Next American Revolution: Sustainable Activism for the Twenty-First Century. Berkeley: University of California Press, 2012.

genre that is ripe for inquiry, as it is rooted in uprising, knowledge of self, and community.

${ }^{69}$ Grace Lee Boggs and Scott Kurashige, The Next American Revolution: Sustainable Activism for the Twenty-First Century (Berkeley: University of California Press, 2012): xxi.

${ }^{70}$ Margaret Wheatley: quoted in Boggs and Kurashige, The Next American Revolutionary: Sustainable Activism for the Twenty-First Century(Berkeley: University of California Press, 2012): 17. 
Bolhman, Philip. "Musicology as a Political Act." The Journal of Musicology 11, no. 4 (Autumn 1993): 411-36. http://dx.doi.org/10.1525/jm.1993.11.4.03a00010.

Born, Georgina, ed. Music, Sound and Space: Transformations of Public and Private Experience. Cambridge: Cambridge University Press, 2013. http://dx.doi.org/10.1017/CBO9780511675850.

Capeci, Dominic J., and Martha Wilkerson. Layered Violence: The Detroit Rioters of 1943. Jackson, MS: University of Mississippi Press, 1991.

Carby, Hazel V. “It Jus Be's Dat Way Sometime: The Sexual Politics of Women's Blues.” In The Jazz Cadence of American Culture, edited by Robert O’Meally, 470-82. New York: Columbia University Press, 1988.

Connell, John, and Chris Gibson. Sound Tracks: Popular Music, Identity and Place. New York: Routledge, 2003. http://dx.doi.org/10.4324/9780203448397.

Cox, Kevin R., and Andrew Mair. "Locality and Community in the Politics of Local Economic Development." Annals of the Association of American Geographers 78, no. 2 (June 1998): 307-25. http://dx.doi.org/10.1111/j.1467-8306.1988.tb00209.x.

Cross, Brian. It’s Not About a Salary: Rap, Race and Resistance in Los Angeles. London: Verso, 1993.

Detroit Future City: 2012 Detroit Strategic Framework Plan. Detroit: Inland Press, 2013.

Farley, Reynolds, Sheldon Danziger, and Harry Holzer. Detroit Divided. New York: Russell Sage Foundation, 2000.

Feld, Steven. "From Ethnomusicology to Echo-Muse-Ecology: Reading R. Murray Schafer in the Papua New Guinea Rainforest.” The Soundscape Newsletter 8 (June 1994): 9-13.

Forman, Murray. The 'Hood Comes First: Race, Space and Place in Rap and Hip Hop. Hanover: Wesleyan University Press, 2002.

Gallagher, John. "When Detroit Paved Over Paradise: The Story of I-375." Detroit Free Press, December 15, 2013. http://www.freep.com/article/20131215/OPINION05/312150060/Black-Bottom-DetroitI-375-I-75-paradise-valley-removal.

Gray, Ross. "Red, Black, and Green: A More Inclusive Environmental Movement Takes the Stage." Orion Magazine, March/April 2014. http://www.orionmagazine.org/index.php/articles/article/8050.

Guy, Nancy. "Flowing Down Taiwan's Tamsui River: Towards an Ecomusicology of the Environmental Imagination.” Ethnomusicology 53, no. 2 (Spring/Summer 2009): 218-48.

Harrison, Anthony Kwame. Hip Hop Underground: The Integrity and Ethics of Racial Identification. Philadelphia: Temple University Press, 2009.

Harvey, David. Social Justice and the City, 2nd ed. Baltimore: Johns Hopkins, 2009.

Hill-Collins, Patricia. Black Feminist Thought: Knowledge, Consciousness, and the Politics of Empowerment. New York: Routledge, 2000.

Howell, Sharon. "Week 18 of the Occupation." The Michigan Citizen, November 12, 2012. http://www.michigancitizen.com/emerging-future.

Ingram, David. The Jukebox in the Garden: Ecocriticism and American Popular Music Since 1960. Amsterdam: Rodopi, 2010.

Kramer, Lawrence. Music as Cultural Practice: 1800-1900. Berkeley, CA: University of California Press, 1993.

Krims, Adam. Music and Urban Geography. London: Routeledge, 2007. 
. Rap Music and the Poetics of Identity. Cambridge: Cambridge University Press, 2000.

Lipsitz, George. "The Possessive Investment in Whiteness: Racialized Social Democracy and the White Problem in American Studies." American Quarterly 47, no. 3 (Autumn 1995): 369-87. http://dx.doi.org/10.2307/2713291.

Manning-Thomas, June. Redevelopment and Race: Planning a Finer City in Postwar Detroit. Detroit: Wayne State University Press, 1997.

McClary, Susan. Feminine Endings: Music, Gender, and Sexuality. Minneapolis, MN: University of Minnesota Press, 1991.

_. "Terminal Prestige: The Case of Avant-Garde Music Composition.” Cultural Critique 12 (Spring 1989): 57-81.

Miller, Karen A. J. "Living in the Arsenal of Democracy: Workers and the Problem of Housing." Paper presented at the North American Labor History Conference, Wayne State University, Detroit, MI, October 2012.

Neff, Ali Colleen. Let the World Listen Right: The Mississippi Delta Hip-Hop Story. Jackson: University Press of Mississippi, 2011.

Ogbar, Jeffrey, O. G. Hip-Hop Revolution: The Culture and Politics of Rap. Lawrence: University of Kansas Press, 2007.

Pedelty, Mark. Ecomusicology: Rock, Folk and the Environment. Philadelphia: Temple University Press, 2012.

Peterson, Marina. Sound, Space, and the City: Civic Performances in Downtown Los Angeles. Philadelphia: University of Pennsylvania Press, 2012.

Rehding, Alexander. "Ecomusicology between Apocalypse and Nostalgia." Journal of the American Musicological Society 64, no. 2 (Summer 2011): 409-14.

http://dx.doi.org/10.1525/jams.2011.64.2.409.

Rose, Tricia. Black Noise: Rap Music and Black Culture in Contemporary America. Hanover: Wesleyan University Press, 1994.

Rosenthal, Debra J. "'Hoods and the Woods: Rap Music as Environmental Literature." The Journal of Popular Culture 39, no. 4 (Summer 2006): 661-76. http://dx.doi.org/10.1111/j.15405931.2006.00284.x.

Schafer, R. Murray. The Tuning of the World. Philadelphia: University of Pennsylvania Press, 1980.

Segrue, Thomas. The Origins of the Urban Crisis: Race and Inequity in Postwar Detroit. Princeton: Princeton University Press, 1996.

Sierra Club. "The State of Detroit's Environment: An Initial Assessment Using the Framework of Environmental Justice.” Accessed January 13, 2014, http://www.SierraClub.org.

Smith, Susan. L. "Soundscape.” Area 26, no. 3 (Summer 1994): 232-40.

Sterne, Jonathan. "Sonic Imaginations." In The Sound Studies Reader, edited by Johathan Sterne, 1-18. New York: Routledge, 2012.

Stimeling, Travis, D. "Music, Place and Identity in the Central Appalachian Mountaintop Removal Debate.” American Music 30, no. 1 (Spring 2012): 1-29. http://dx.doi.org/10.5406/americanmusic.30.1.0001.

Thompson, Heather Ann. Whose Detroit?: Politics, Labor, and Race in a Modern American City. Ithaca: Cornell University Press, 2004. 
Throsby, David. The Economics of Cultural Policy. Cambridge: Cambridge University Press, 2010. http://dx.doi.org/10.1017/CBO9780511845253.

Von Glahn, Denise. Music and the Skillful Listener: American Women Compose the Natural World. Bloomington, IN: Indiana University Press, 2013. 


\begin{abstract}
This paper examines how a collective of women in Detroit are using hip hop culture and rap music specifically to create spaces of resistance in a place inundated with environmental ruins, race politics, social alienation, and dilapidated living conditions. It contextualizes the historical and contemporary environmental situation of Detroit before moving on to examine the collective process of creating the rap song and music video "Legendary." Ecomusicological and urban planning literature, along with Adam Krims's concepts of design intensity, cultural regeneration, and urban ethos, are reconfigured in relation to socially conscious, women-centered hip hop. "Legendary" locates Detroit's contemporary struggles in racially marked places in the city through an array of arresting images that capture environmental waste, forgotten spaces, and resilience among residents to survive such challenges. Ultimately, we argue that the video serves as an example of how music can be used to question gendered power dynamics in hip hop culture and its connection to the environment, creating more desirable, sustainable communities.
\end{abstract}

